\title{
The Macroeconomic Effects of German Fiscal Austerity under Different Exchange Rate Regimes: The Experience of Central and Eastern European Countries ${ }^{*}$
}

\begin{abstract}
According to a familiar two-country Mundell-Fleming framework, the policy of fiscal austerity in Germany should be restrictionary for other European countries with a floating exchange rate, while there is a possibility of an expansionary effect for countries with a peg. Using quarterly data of eight Central and Eastern European countries over the 2002-2014 period, it is found with a four-variable VAR model that fiscal austerity in Germany leads to an increase in the money supply and output, while the effects on the real exchange rate are marginal. Our results contrast with several other studies, that imply that the policy of fiscal stimulus in Germany is beneficial for other European countries. Our results could be interpreted in such a way that demand and competitiveness effects are outweighed by the effect of international flows. A strongest expansionary effect is obtained for Bulgaria, Slovakia and Latvia, which maintain fixed exchange rates, while

Viktor Shevchuk, Cracow University of Technology, Institute of Economics, Sociology and Philosophy, 31-155 Kraków, ul. Warszawska 24, Poland, e-mail: vshevchuk@pk.edu.pl

Roman Kopych, Ivan Franko National University of Lviv, Department of International Economic Relations, 79000 Lviv, 1 Universytetska str, Ukraine, e-mail: kopych_r@bigmir.net

* The authors gratefully acknowledge financial support from the Cracow University of Technology (research project F-4/30/2014/DS).
\end{abstract}


expansionary effects are weaker for countries with greater exchange rate flexibility, such as Poland, Hungary and the Czech Republic.

Keywords: fiscal austerity, Germany, exchange rate regime, Central and Eastern European countries, the Mundell-Fleming model.

JEL Classification: C5, E6, H6.

\section{Introduction}

It is quite common to blame Germany's policy of fiscal austerity for slow recovery in the eurozone and other European countries (Karger 2014, pp. 33-53; Krugman 2013; Zezza 2012, pp. 37-54), especially in the post-crisis economic environment. There is no lack of arguments maintaining that the government-spending multiplier can be much larger than the one used during recessions (Auerbach \& Gorodnichenko 2012, pp. 1-27), financial crises (Corsetti, Meier \& Müller 2012, pp. 521-565) and/or if monetary policy is constrained by the zero lower bound (ZLB) on the nominal interest rates (Christiano, Eichenbaum \& Rebelo 2011, pp. 78-121). However, fiscal austerity can be justified when public debt and sovereign risk are high (Müller 2014, pp. 243-258; Ilzetzki, Mendoza \& Végh 2013, pp. 239-254). Also, uncertainty about fiscal policy can cause large declines in consumption, investment, and output under ZLB, thus reversing one of the most powerful arguments in favour of fiscal stimuli and the accumulation of public debt (Johannsen 2014). If austerity in Germany reduces uncertainties related to the sovereign debt in the euro area, it can contribute to deviations of sovereign borrowing costs from their long-run equilibrium levels (Veld 2013).

In the wider context of an open-economy setting, traditional analysis based on the Mundell-Fleming model implies that the fiscal multiplier is larger under a fixed exchange rate system, while it is supposed to be zero in economies with a freely floating exchange rate (Born, Juessen \& Müller 2013, pp. 446-465). More open economies are supposed to have stronger fiscal spillovers due to larger trade and capital flows, although the combined effect depends on the relative strength of foreign demand, relative price and capital flow channels (Veld 2013).

For an unbalanced panel of OECD countries over the 1985 to 2011 period, it has been found by Born, Juessen and Müller (2013, pp. 446-465) that the difference in the fiscal multiplier across exchange rate regimes is driven by differences in the monetary policy stance, as in the Mundell-Fleming model, but that is due to the level of private expenditure being adjusted rather than a redirection of trade flows. Similar results were obtained by Cardi and Müller (2011, pp. 256-267) for an open economy version of the neoclassical model with endogenous terms of trade and habit persistence in consumption, as the current account tends to be 
larger and the effects on output more routed in more open economies. Assuming asymmetrical changes in the current account, this implies a stronger positive spillover effect of German austerity on other European countries. However, the empirical results do not provide support for austerity spillovers in European countries (Beetsma, Giuliodori \& Klaassen 2006, pp. 640-697; Ivanova \& Weber 2011).

The aim of this study is to examine, using empirical evidence, the importance of German fiscal austerity upon several Central and Eastern European (CEE) countries, with a focus upon exchange rate regimes. A two-country Mundell-Fleming model is used as the framework for explaining potential differences between fiscal spillovers under fixed and floating exchange rate regimes. Among the countries to be studied, the Czech Republic, Hungary, Poland and Romania have maintained a floating exchange rate regime, while Bulgaria, Slovakia, Estonia and Latvia have followed a policy of exchange rate stability.

The remainder of the paper is organised as follows. Section 2 presents the theoretical framework. Section 3 outlines the data and statistical methodology. Section 4 discusses the estimation results and Section 5 concludes.

\section{Theoretical Framework}

For the purpose of explaining the basic relationships, a two-country Mundell-Fleming model is used (in logs), as follows (McCallum 1996, pp. 111-115):

a) CEE countries

$$
\begin{gathered}
y_{t}=a_{0}+a_{1}\left(m_{t}-p_{t}\right)+a_{2} g_{t}-a_{3} r_{t}+a_{4} q_{t}+a_{5} y_{t}^{*}, \\
m_{t}-p_{t}=b_{0}+b_{1} y_{t}-b_{2} R_{t}, \\
r_{t}=R_{t}-\left(E_{t} p_{t+1}-p_{t}\right), \\
r_{t}=r_{t}^{*}+E_{t} e_{t+1}-e_{t}, \\
q_{t}=e_{t}+p_{t}^{*}-p_{t},
\end{gathered}
$$

b) Germany

$$
\begin{gathered}
y_{t}^{*}=a_{0}+a_{1}\left(m_{t}^{*}-p_{t}^{*}\right)+a_{2} g_{t}^{*}-a_{3} r_{t}^{*}-a_{4} q_{t}+a_{5} y_{t}, \\
m_{t}^{*}-p_{t}^{*}=b_{0}+b_{1} y_{t}^{*}-b_{2} R_{t}^{*}, \\
r_{t}^{*}=R_{t}^{*}-\left(E_{t} p_{t+1}^{*}-p_{t}^{*}\right),
\end{gathered}
$$

where $y_{t}$ and $y_{t}^{*}, R_{t}$ and $R_{t}^{*}, r_{t}$ and $r_{t}^{*}, g_{t}$ and $g_{t}^{*}, m_{t}$ and $m_{t}^{*}$ are domestic and foreign income (output), nominal and real interest rates, budget deficit, and money supply, respectively, $q_{t}$ and $e_{t}$ are real and nominal exchange rates (domestic currency price of foreign exchange), with $p_{t}$ and $p_{t}^{*}$ denoting domestic and foreign price indexes, $E_{t} e_{t+1}$ are expectations of exchange rate depreciation. 
As an open economy extension of the familiar IS-LM model, the Mundell-Fleming model accounts for the balance-of-payments (BOP) constraints, in addition to equilibrium conditions on the goods and services market (IS) and on the money market (LM). Taking into account the BOP equilibrium (the Mundell-Fleming is often referred to as the IS-LM-BP model), it is possible to establish the neutrality of fiscal policy in respect to income for the floating exchange rate regime under perfect capital mobility measured as the capital flows' sensitivity to the interest rate differential between the home country and world financial markets being in sharp contrast to the maximum effectiveness of expansionary fiscal policy under a fixed exchange rate regime. For a fixed exchange rate regime, the Mundell-Fleming model implies money supply neutrality in respect to income under assumption of a small open economy, but this result does not hold in the case of a two-country setting. For comparison, the IS-LM model implies an increase in income following both fiscal and monetary expansions.

Equations (1) and (6) present familiar IS relationships for both economic areas. The usual assumption is that national income is determined by the budget deficit, the wealth effect (determination of private consumption by the real money supply), the real interest rate, relative prices and income abroad. Fiscal stimulus expands demand and thus should have favourable spillovers to foreign trade partners through a higher demand for their exports. On the other hand, a likely demand-driven increase in domestic prices should inhibit exports and enhance imports, thus weakening the magnitude of income expansion. Both demand and relative price effects are favourable for trade partners. The outcomes are just the opposite for fiscal austerity, which is supposed to reduce domestic demand and growth, with a negative spill-over effect in other countries.

Money market equilibriums are defined in equations (2) and (7). Money supply is determined in real terms. As is assumed in the LM framework, demand for real money is proportional to output and inversely related to the interest rate. Equations (6)-(8) for Germany are analogous to equations (1)-(3) for the CEE countries, with $y_{t}$ playing the same role in (6) as $y_{t}^{*}$ does in (1). For simplicity, the values of the $a_{i}$ and $b_{i}$ parameters are assumed to be the same across both economic areas, but this restriction is not crucial for the analysis of fiscal policy issues.

While the real interest rate $r_{t}$ is relevant to the IS specification of supply and demand choices in the loan market, the demand for real money balances, according to the LM function, is based upon the nominal rate of interest $R_{t}$. In equation (3), the real interest rate $r_{t}$ is the difference between the nominal interest rate $R_{t}$ and the expected or anticipated value of $E_{t} p_{t+1}-p_{t}$ as of period $t$. As specified in equation (4), the real interest rate is dependent upon expectations of nominal exchange rate depreciation. The uncovered interest parity is based on the assumption that domestic and foreign securities are close substitutes, but their yields are not equal 
due to determination in different currencies. If it is expected that the domestic currency will depreciate over the next period, then one-period interest rates in the home economy will tend to rise.

The real exchange rate (RER) is defined in equation (5) on the purchasing power parity basis, implying that relative prices are dependent upon a nominal exchange rate and domestic (CEE countries) and foreign (Germany) price levels.

Assuming price stability $\left(E_{t} p_{t+1}=p_{t}\right)$ and the lack of expectations of exchange rate depreciation $E_{t} e_{t+1}=e_{t}$, it is not only the real and nominal rates that are equal $\left(r_{t}=R_{t}\right)$, but nominal rates in both economic areas become equal as well $\left(R_{t}=R_{t}^{*}\right)$. For the purpose of short-run analysis with sticky prices and perfect capital mobility $\left(r_{t}=r_{t}^{*}\right)$, the list of endogenous variables under a fixed exchange rate regime becomes as follows: $y_{t}, y_{t}^{*}, r_{t}, m_{t}, m_{t}^{*}$. For a floating exchange rate regime, the endogenous variables are: $y_{t}, y_{t}^{*}, r_{t}, e_{t}$, and $q_{t}$. Assuming a stable money supply in a two-country system $(\bar{M}=$ const $), q_{t}$ also becomes an endogenous variable for a fixed exchange rate regime.

Figures 1 and 2 show the short-run response in both economic areas to a decrease in the budget deficit in Germany alone under assumptions of a floating and a fixed exchange rate, respectively. Since $a_{3}<0$, the IS curve representing equations (1) and (6) is downward sloping in the $r-y$ plane. As demand for money increases in line with the level of income, the $L M$ curve will slope upward.

The policy of fiscal austerity in Germany shifts $I S_{0}^{*}$ to $I S_{1}^{*}$, which results in a decrease in income from $Y_{0}^{*}$ to $Y_{1}^{*}$ and downward pressure on the interest rate. As there is a contraction in Germany, it reduces demand for exports from CEE countries, shifting their demand scheduler downward from $I S_{0}$ to $I S_{1}$. Further, because the interest rate in Germany at $r_{1}^{*}$ is not consistent with equilibrium, some adjustment is needed. In models (1)-(8), the interest rate differential in favour of CEE countries results in capital inflow from Germany followed by exchange rate appreciation. Consequently, demand recovers to $I S_{2}^{*}$ in Germany and further falls to $I S_{2}$ in the CEE countries. The new equilibrium is such that income decreases in both economic areas while the exchange rate appreciates in the CEE countries. On the whole, austerity policy in Germany seems to be counterproductive, as its opponents used to argue.

However, macroeconomic developments could be quite different under exchange rate stability. While fiscal austerity is still restrictionary for Germany, it is possible to obtain an expansionary spillover to the CEE countries (Fig. 2). As in the previous case of a floating exchange rate, a decrease in the budget deficit shifts demand in Germany leftward from $I S_{0}^{*}$ to $I S_{1}^{*}$. This time, however, capital outflow from Germany is combined with a decrease in the money supply from $L M_{0}^{*}$ to $L M_{1}^{*}$, which deepens the fall in income to $Y_{2}^{*}$. On the other hand, monetisation of capital inflows to CEE countries, as shown by the rightward shift of 


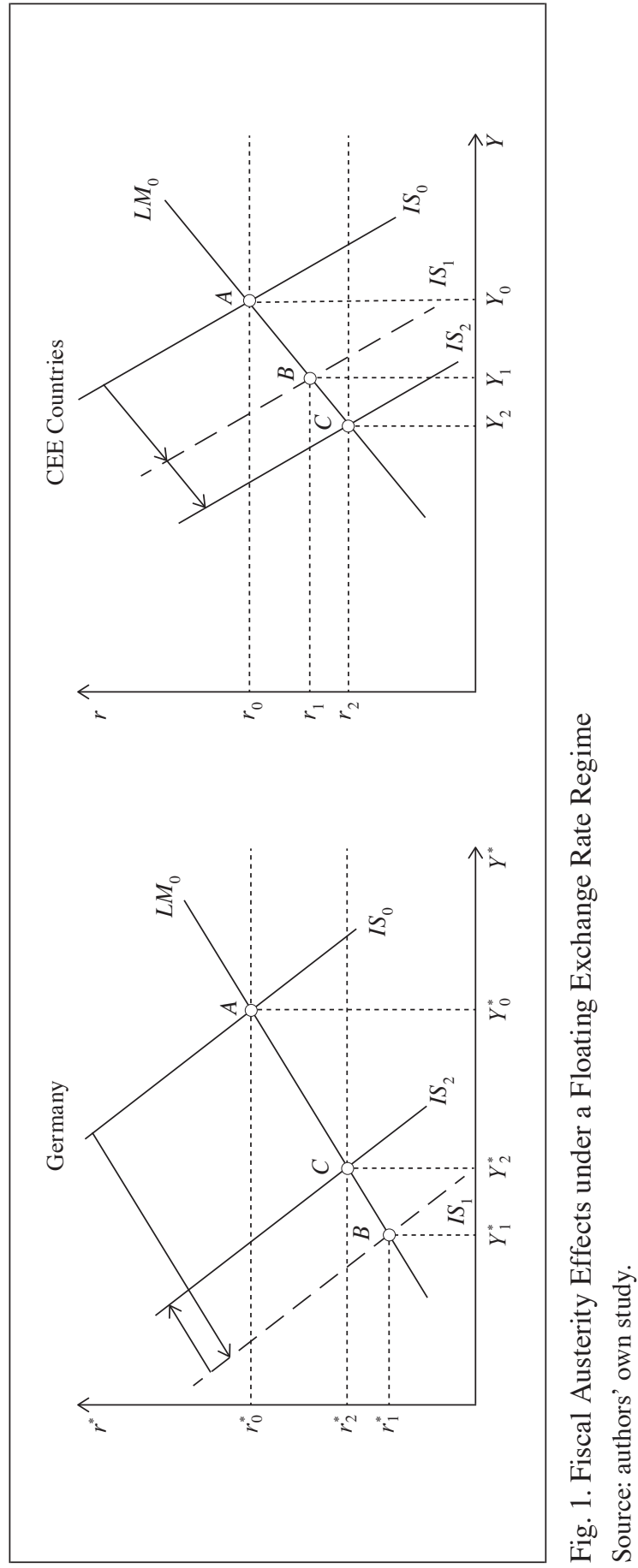


The Macroeconomic Effects of German Fiscal Austerity...

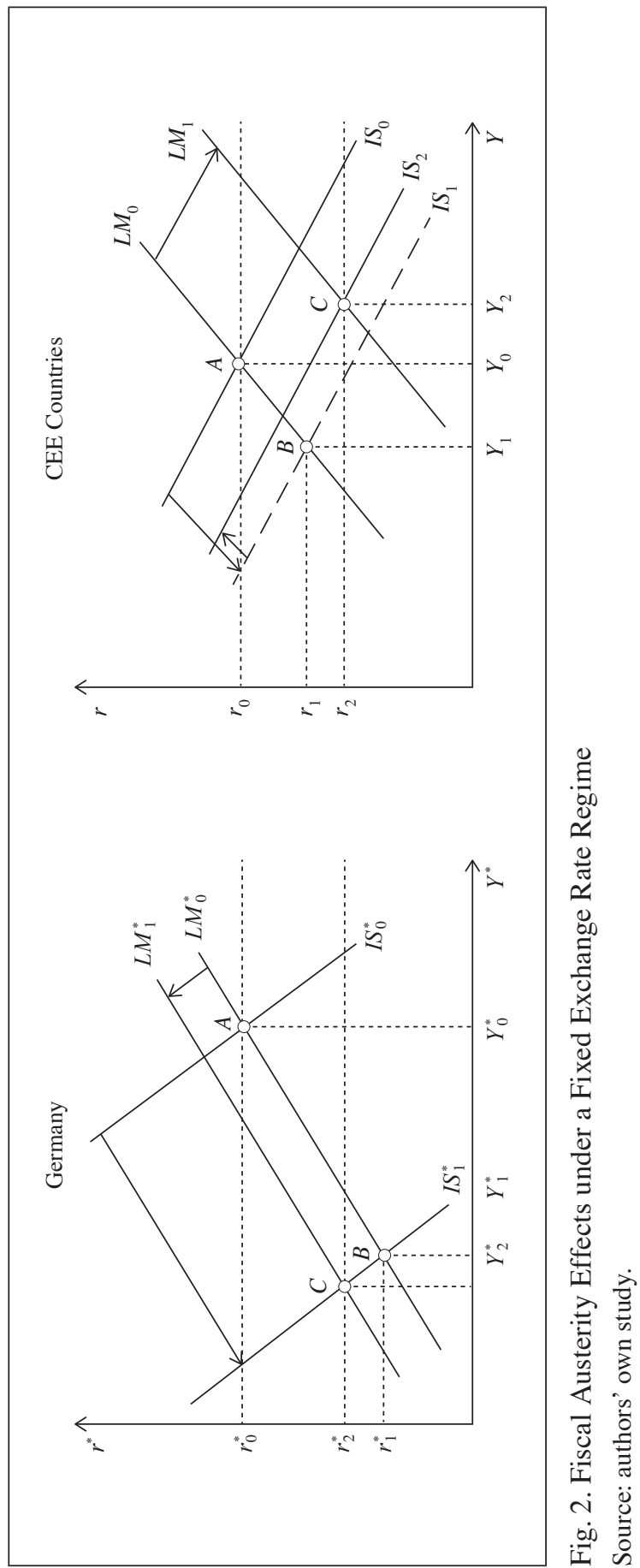


$L M$ scheduler from $L M_{0}$ to $L M_{1}$, allows the initial downward shift in demand from $I S_{0}$ to $I S_{1}$ to be neutralised, with an expansionary outcome not being ruled out. The expansionary effect is more likely in the cases of 1) higher income elasticity in respect to the interest rate, 2) a larger interest rate differential and 3) a stronger wealth effect in the demand for goods and services. Following an increase in the money supply, there is an increase in demand from $I S_{1}$ to $I S_{2}$, which helps to compensate partially for an initial fall in demand due to a lower level of income abroad, i.e. in Germany.

All said, maintaining a fixed exchange rate regime seems to offer CEE countries much better prospects for avoiding a decline in income by way of a fiscal austerity policy in Germany. Another possible source of an expansionary spillover is the endogeneity of risk premium in respect to fiscal austerity abroad. If there is a decline in the risk premium due to fiscal austerity, it should stimulate demand in the private sector and thus contribute to an increase in income.

\section{Data and Statistical Methodology}

Our VAR model includes four variables: the budget balance in Germany (as a percent of GDP), bdger , the money supply (in percentage points of money aggregate $\mathrm{M} 2$ relative to trend), $m c_{t}$, the log of the real effective exchange rate (index, $2010=100$ ), rer $_{t}$, output (in percentage points of GDP relative to trend), $y c_{t}$. Quarterly data for the 2002-2014 period are used, dependent on the availability of particular time series for individual countries. Data on the German budget balance are obtained from the Eurostat database. All other series are obtained from the IMF's International Financial Statistics database (www.imf.org).

Germany's budget balance is used in its structural form, i.e. adjusted for a lagged business cycle position. As presented in Fig. 3, the budget surplus had been substantial over the 2006-2008 period and again in 2011-2012, with a somewhat smaller surplus since then. According to the Augmented Dickey-Fuller (ADF), it is not possible to reject the null hypothesis of a unit root for the cyclically adjusted German budget balance at a 1-percent level of confidence; however, that is not the case for the unadjusted budget balance series.

Because the money supply and output series are used in their cyclical form, both variables are stationary across all countries (Table 1). The same conclusion could be drawn in respect to the first differenced RER series. According to the ADF tests, no significant differences are observed between the countries with a floating exchange rate (the Czech Republic, Poland, Hungary and Romania) and those with a fixed exchange rate (Bulgaria, Slovakia, Estonia and Latvia). As suggested by the Johansen test, there is no co-integration between $b d g e r_{t}$, 
$m c_{t}, \Delta r e r_{t}$, and $y c_{t}$ (the results are not reported in this article but are available on request). Consequently, the use of the VAR model including all four endogenous variables is quite reasonable.

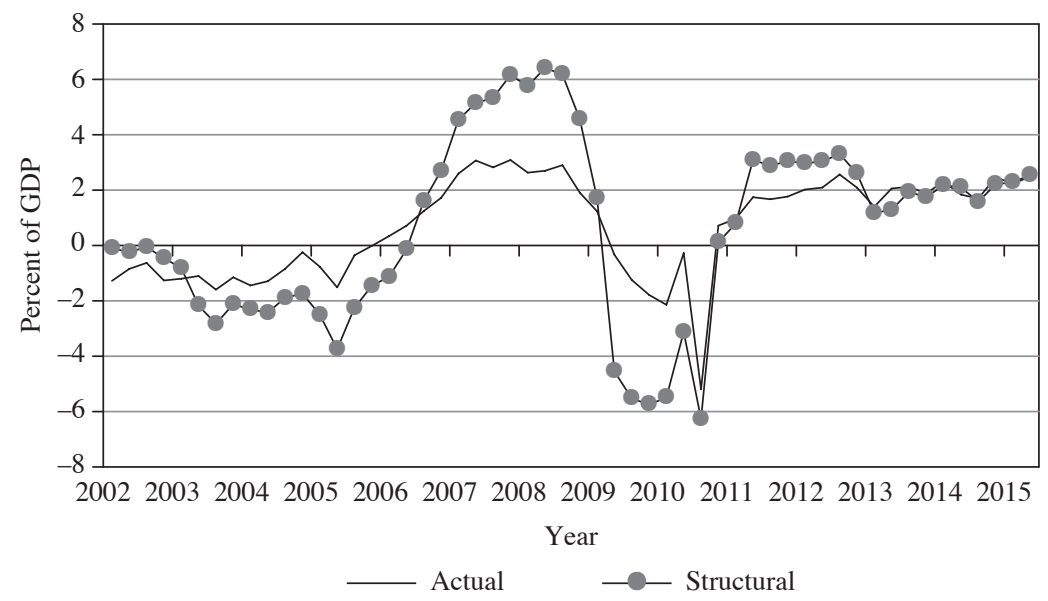

Fig. 3. Germany's Budget Balance (Percent of GDP), 2002-2015

Source: www.ec.europa.eu/eurostat/web/products-datasets.

Table 1. Augmented Dickey-Fuller (ADF) Test

\begin{tabular}{|l|c|c|c|c|}
\hline \multicolumn{1}{|c|}{ Country } & Data sample & $m c_{t}$ & $\Delta r e r_{t}$ & $y c_{t}$ \\
\hline Czech Republic & 2002Q1:2014Q4 & $-1.99^{* *}$ & $-7.33^{* * *}$ & $-1.64^{*}$ \\
\hline Poland & 2002Q1:2015Q1 & $-3.14^{* * *}$ & $-6.58^{* * *}$ & $-2.11^{* *}$ \\
\hline Hungary & $2002 \mathrm{Q} 1: 2014 \mathrm{Q} 4$ & $-2.51^{* *}$ & $-6.79^{* * *}$ & $-2.95^{* * *}$ \\
\hline Romania & 2002Q1:2014Q4 & $-10.44^{* * *}$ & $-5.46^{* * *}$ & $-3.14^{* * *}$ \\
\hline Bulgaria & $2002 \mathrm{Q} 1: 2014 \mathrm{Q} 4$ & $-2.28^{* *}$ & $-2.48^{* *}$ & $-3.56^{* * *}$ \\
\hline Slovakia & $2002 \mathrm{Q} 1: 2008 \mathrm{Q} 4$ & $-2.15^{* *}$ & $-4.30^{* * *}$ & $-2.41^{* *}$ \\
\hline Estonia & $2002 \mathrm{Q} 1: 2010 \mathrm{Q} 4$ & $-2.45^{* *}$ & $-2.44^{* *}$ & $-2.96^{* * *}$ \\
\hline Latvia & $2002 \mathrm{Q} 1: 2013 \mathrm{Q} 3$ & $-2.01^{* *}$ & $-5.22 * * *$ & $-2.79^{* * *}$ \\
\hline
\end{tabular}

Note: $* * *$ null hypothesis of a unit root can be rejected at a 1-percent, $* *-$ at a 5-percent and $*_{-}$at a 10-percent level of confidence.

Source: authors' own study.

When the endogenous variables are collected in the $k$-dimensional vector $X_{t}$, the reduced-form VAR model can be expressed as follows:

$$
X_{t}=C+A(L) X_{t-1}+u_{t},
$$


where $C$ includes deterministic terms (both constant and linear trend), $A(L)$ is a matrix polynomial in the lag operator $L$, and $u_{t}$ is a $k \times 1$ vector of reduced-form disturbances which are assumed to be normally distributed white noise $\mathrm{E}\left[u_{t}\right]=0$ with a constant covariance matrix $\boldsymbol{E}\left[u_{t} u_{t}^{\prime}\right]=\Sigma_{u}$ and $\boldsymbol{E}\left[u_{t} u_{s}^{\prime}\right]=0$ for $s \neq t$.

The vector of endogenous variables, $X_{t}$, is given by $X_{t}=\left[\right.$ bdger $\left._{t}, m c_{t}, \Delta r e r_{t}, y c_{t}\right]$. It is assumed that the German budget balance affects the money supply and/or RER on impact. Then the foreign income, money supply and relative price effects are responsible for changes in the business cycle.

As suggested by the Akaike criterion, VAR models with one lag are estimated for Estonia and Latvia, with two lags for Hungary, Poland and Slovakia, with three lags for the Czech Republic and Romania, and with four lags for Bulgaria. Among the exogenous variables, the London Interbank Offer Rate (LIBOR) and a dummy for the 2008-2009 financial crisis are used in order to improve the statistical properties of individual country VAR models. In all cases, VAR model residuals have passed stationarity tests.

While a panel VAR model quite often is considered a better way of estimating relationships between macroeconomic variables with a focus upon generalised policy implications, it is perhaps more viable to start with individual country studies. First, there could be important heterogeneity in the macroeconomic relationships across individual countries explained by structural features or policy regimes, such as the choice of the exchange rate system, which is masked by pooling the data. Consequently, it may be misleading to draw a general policy implication that applies to a broad group of countries on the basis of panel model estimates. Second, individual country studies allow for useful comparisons and classifications across different analytical channels. It is then possible to generalise the results with a panel VAR in order to obtain estimates not affected by significant domestic differences. For example, a panel VAR could provide somewhat stronger evidence in support of fiscal spillovers if it did not account for differences across country-specific exchange rate arrangements.

\section{Estimation Results}

Our results for the VAR model regarding the dynamic effects of an exogenous increase in Germany's budget balance upon the RER, money supply and output of eight CEE countries are presented in Fig. 4 to 6, respectively (EViews 6.1 software was used to make the computations). On the vertical axes, the RER is measured in first differences of its log-level (Fig. 4), and both money supply and GDP are measured in the percentage deviation from trend. The horizontal axis measures time in quarter units. For analytical comparisons, the impulse responses of our 
four-variable VAR model (in blue) are presented jointly with impulse responses for a three-variable VAR model with no money supply (red).

Regardless of the exchange rate regime and other country-specific features, Germany's budget balance seems not to have any significant effect on the RER (Fig. 4). Results do not differ from those obtained from a VAR model with three variables not including money supply (in red). Romania is the only country showing a statistically significant effect on impact, but it is short-lived. Contrary to the predictions of the Mundell-Fleming model, fiscal austerity in Germany is associated with a sharp depreciation of the local Romanian currency. In general, there is no support for the results obtained by Born, Juessen and Müller (2012, pp. 446-465): specifically, that the RER appreciates significantly under the peg following an expansionary fiscal shock (this implies depreciation of the RER for fiscal austerity). It should be mentioned, however, that they studied the effects of domestic fiscal policy, not spillovers from foreign fiscal shocks.

As expected, fiscal austerity in Germany led to an increase in the money supply in Bulgaria and Slovakia, both of which maintained a fixed exchange rate regime (Fig. 5). However, the same relationship is observed for the Czech Republic, Poland and Romania, which have followed a floating exchange rate policy. This could be seen as an argument favouring 'fear of floating', when the central bank tries to avoid any deviations from the perceived equilibrium trend which are considered excessive $^{1}$. Ultimately, a de jure floating exchange rate regime starts to resemble a peg when the money supply adjusts to external macroeconomic shocks, such as that of fiscal austerity in Germany. In this respect, our results contrast with the findings of Windberger, Crespo Cuaresma and Walde (2012) made on the basis of weekly data for changes in the three-month interbank rate and the exchange rates vis-à-vis the euro that the Czech Republic, Hungary and Poland have had a significant degree of monetary independence over the 2002-2011 period.

For Hungary, a decrease in the money supply on impact is reversed with six to eight quarter lags, probably reflecting the effects of sterilisation policy. On the other hand, the link between fiscal austerity in Germany and domestic money supply was not detected for Latvia or, to a lesser extent, Estonia, as such austerity is not consistent with the standard assumptions for a fixed exchange rate that both countries have been practicing over the last decade. One explanation could be the central bank's attempt to sterilise the capital inflows in order to avoid likely inflationary developments.

${ }^{1}$ Formally, the term 'fear of floating' characterises a situation where the announced intention to float a currency is not honoured in deeds as well as in words, reflecting the lack of central bank credibility, a high pass-through of exchange rates to prices and inflation targeting (Calvo \& Reinhart 2002, pp. 379-408). One of the recent explanations of the fear of floating refers to the central bank overestimation of the unfavourable balance sheet effect (Bigio 2010, pp. 1923-1950). 


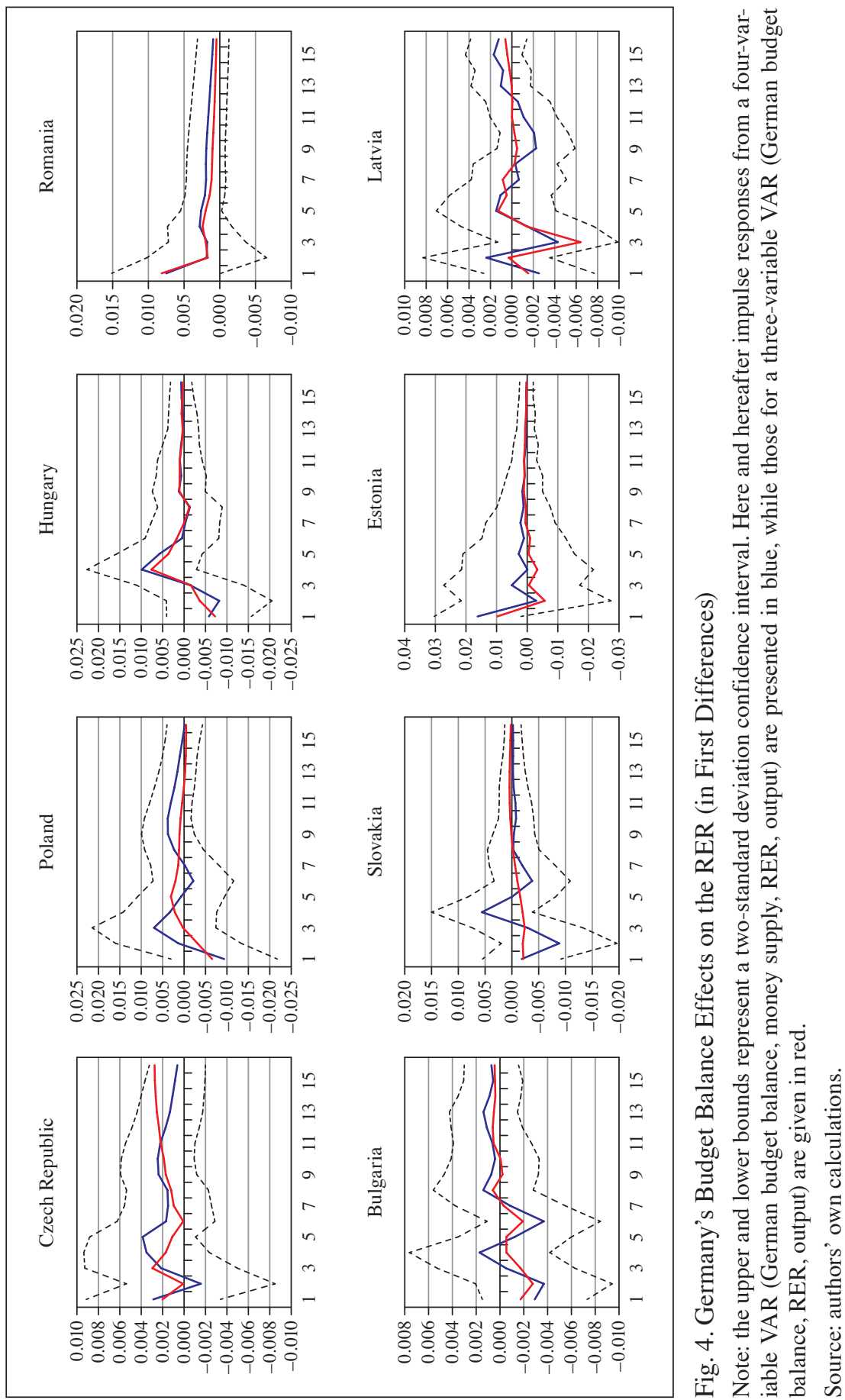



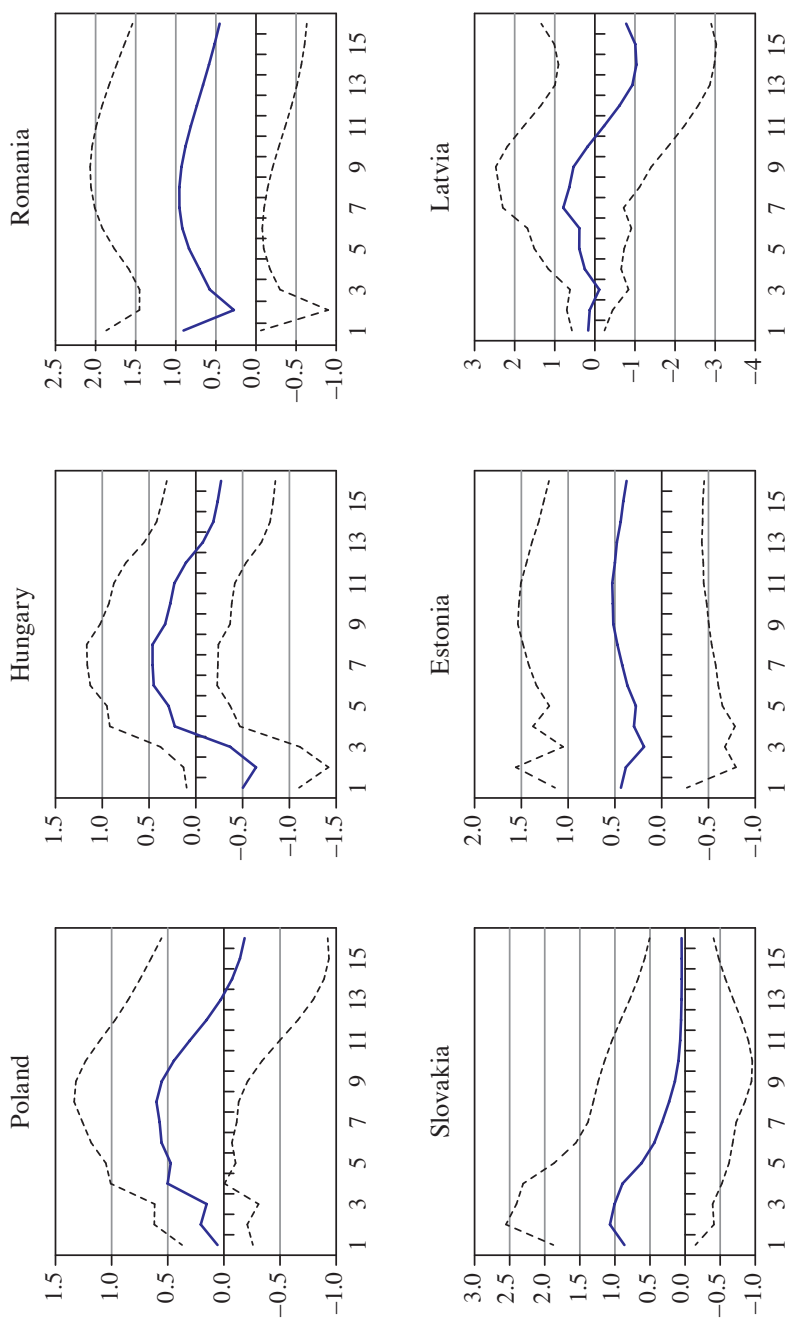

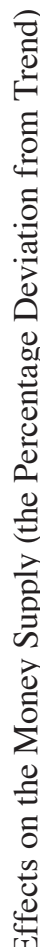
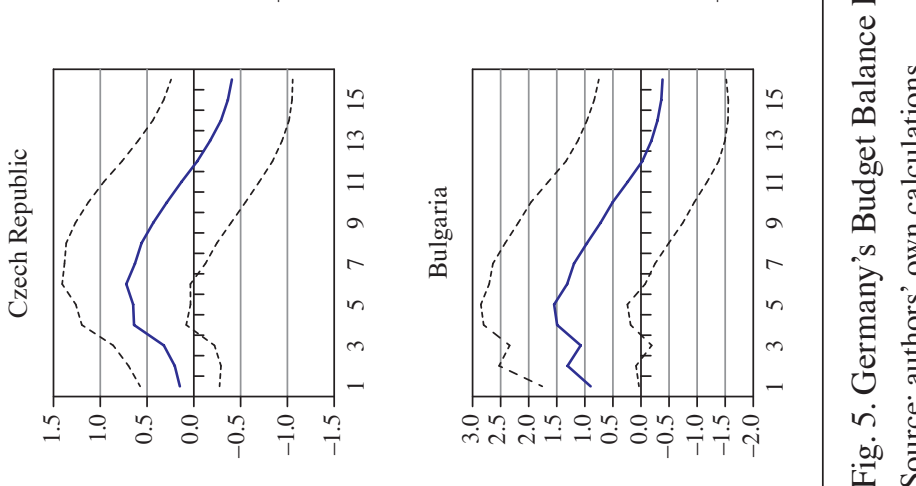
For all countries, the response of output to German austerity is uniformly positive in the short run, with a gradual decline after the initial impulse (Fig. 6). However, there are several differences in the dynamic adjustment across exchange rate regimes as well as between countries with a floating exchange rate regime. Under fixed rates, the average quarterly effect ranges between 0.22 (Estonia) and 0.55 (Slovakia) for the first year after the shock. This means that a percentage point of an improvement in Germany's budget balance contributes to an increase in GDP above its trend by 0.22 and $0.55 \%$, respectively. For Estonia, the positive spillover effect is as high as $0.68 \%$ of cyclically adjusted output growth, but it fades quickly. For three other countries with a fixed exchange rate, the impact of German austerity is quite persistent, as during the second year the magnitude of the effect declines only by a third.

It is worth noting that accounting for a money supply channel does not much change the the shape of the impulse function for Bulgaria and Latvia, but some differences are observed for Slovakia and Estonia. In Slovakia, the effect of fiscal austerity on impact becomes insignificant, with a somewhat stronger effect in the long run if it is compared with a VAR model without including the money supply. For Estonia, the difference in results between the two VAR models is just the opposite. If the money supply effects are not controlled for, the pro-growth effect of German fiscal austerity becomes much stronger on impact, while undergoing a deeper correction in the long run.

With the exception of Romania, the impact of German austerity is much weaker and less persistent for countries with a floating exchange rate regime. The impact effect for the Czech Republic, Hungary and Poland comes in at 0.31, on average, per quarter, which is about half of the effect upon countries with a fixed exchange rate regime (excluding Estonia). Moreover, the fiscal spillover fades away completely during the second year after the austerity shock for Hungary and the Czech Republic, while being halved for Poland. For Hungary and the Czech Republic, there is evidence that a short-run expansionary effect is reversed with a lag of eight to 12 quarters; the fiscal shock from Germany then becomes neutral in respect to output. As for Romania, the second-year effect increases to 0.49, which has similarities to Latvia and Slovakia that follow a different exchange rate peg policy. In accordance with policy implications for a floating exchange rate regime, there is little difference between the impulse response functions of VAR models with and without the money supply as the endogenous variable.

Our estimates support previous studies (for instance, see Born, Juessen and Müller 2013, pp. 446-465) which have found that fiscal multipliers are larger under a peg. However, there is no support for the findings of Beetsma, Giuliodori and Klaassen (2006, pp. 640-687) that a fiscal stimulus in Germany leads to an increase in output abroad. For the CEE countries, it is just the opposite. Among 

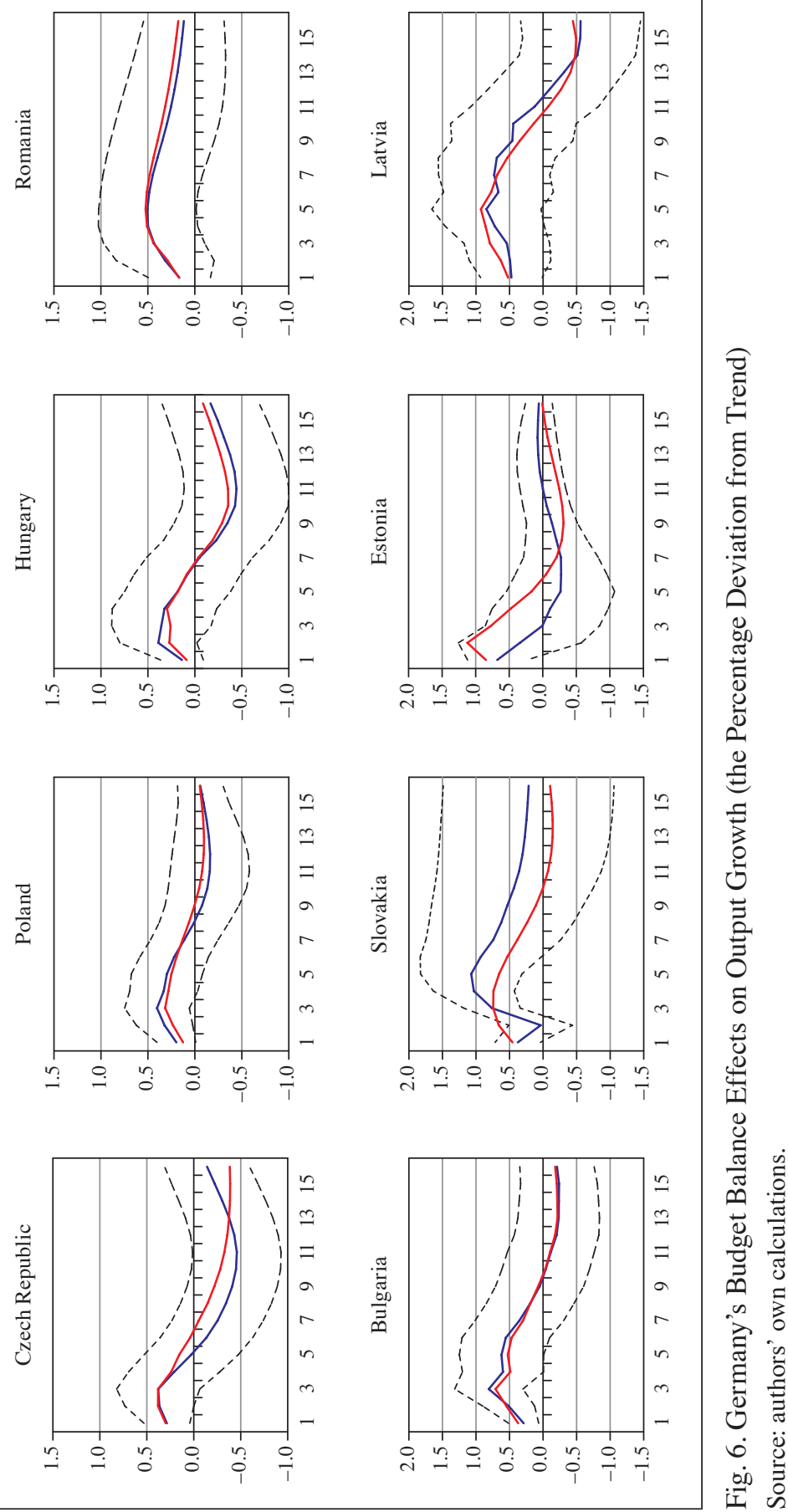
different spillover channels, our results suggest that demand and competitiveness effects are outweighed by the effect of international flows. It could be argued that Germany's austerity is associated with lower uncertainty related to the sovereign debt and thus contributes to capital inflows into the CEE countries.

Table 2 reports the portion of the forecast error variance decomposition (FEVD) in the money supply, real exchange rate and output at different forecast horizons that is attributable to innovations in Germany's budget balance. It is not surprising that the highest share of Germany's budget balance in changes in the money supply is observed for Bulgaria and Slovakia, both of which have a fixed exchange rate regime. However, the money supply in Estonia and Latvia seems to be insulated from an external fiscal shock of German origin. Among countries with a floating exchange rate regime, Germany's budget balance amounts to a quarter of FEVD for the money supply for the Czech Republic and Romania, with a smaller share for Hungary and Poland.

Fiscal spillovers do not play a significant role in relative prices, as their contribution to changes in the RER is below $15 \%$ for six of the eight countries. It is only for Poland and Slovakia that the share of Germany's budget balance in the FEVD of RER approaches $20 \%$. When compared with the results for a VAR model without the money supply, an extended VAR model yields a higher share for Germany's budget balance in the FEVD of RER for all countries except Hungary and Romania.

Slovakia is the most dependent on the German fiscal shock, with its share in the FEVD of output gradually decreasing from as high as 67\% to $31 \%$. German fiscal shocks account for a significant portion of changes in output for Bulgaria and the Czech Republic (above 30\% at different time horizons), Latvia (between 20 and 30\%), and Hungary and Romania (between 10 and 30\%). For Estonia and Poland, fiscal spillovers seem to be much weaker. If compared with the results of a VAR model without model supply, there is a twofold increase in the share of German budget balance in the FEVD of output for the Czech Republic, with a decrease of the same magnitude for Poland. The results are comparable for the other countries.

Among other results, it is found that the RER depreciation contributes to a temporary increase in output above its trend in Estonia and Latvia (however, its contribution to changes in the business cycle does not exceed $10 \%$ ), while the opposite short-run contractionary effect is observed in the Czech Republic (up to $30 \%$ ) and Bulgaria (20\%). For Hungary, Poland, Romania and Slovakia, the RER does not play any role in the business cycle.

The money supply is expansionary mostly in the countries with a peg, and its share in the FEVD of output stands at 30\% for Bulgaria, 15\% for Estonia and $10 \%$ for Latvia. However, excessive money supply proved highly restrictionary 
in Slovakia, where about two-thirds of the changes in output is money-based. Changes in the money supply do not affect output in any of the countries with a floating exchange rate.

Table 2. Forecast Error Variance Decomposition

\begin{tabular}{|c|c|c|c|c|c|c|}
\hline \multirow{2}{*}{ Responses of } & \multirow{2}{*}{ Innovations in } & \multirow{2}{*}{ Country } & \multicolumn{4}{|c|}{ Forecast horizons } \\
\hline & & & 4 & 8 & 12 & 16 \\
\hline \multirow{8}{*}{$\begin{array}{l}\text { Money supply } \\
\left(m c_{t}\right)\end{array}$} & \multirow{8}{*}{ bdger $_{t}$} & Czech Republic & 12 & 25 & 24 & 27 \\
\hline & & Hungary & 14 & 17 & 18 & 19 \\
\hline & & Poland & 18 & 14 & 13 & 13 \\
\hline & & Romania & 8 & 17 & 23 & 26 \\
\hline & & Bulgaria & 27 & 39 & 40 & 39 \\
\hline & & Slovakia & 29 & 32 & 30 & 30 \\
\hline & & Estonia & 6 & 7 & 11 & 13 \\
\hline & & Latvia & 3 & 6 & 7 & 8 \\
\hline \multirow{8}{*}{$\begin{array}{l}\text { Real exchange } \\
\text { rate }\left(\Delta r e r_{t}\right)\end{array}$} & \multirow{8}{*}{ bdger $_{t}$} & Czech Republic & 4 & 6 & 9 & 9 \\
\hline & & Hungary & 10 & 11 & 11 & 11 \\
\hline & & Poland & 17 & 17 & 17 & 18 \\
\hline & & Romania & 7 & 9 & 10 & 11 \\
\hline & & Bulgaria & 7 & 9 & 9 & 10 \\
\hline & & Slovakia & 18 & 20 & 20 & 20 \\
\hline & & Estonia & 12 & 12 & 12 & 12 \\
\hline & & Latvia & 9 & 8 & 9 & 10 \\
\hline \multirow{8}{*}{ Income $\left(y c_{t}\right)$} & \multirow{8}{*}{ bdger $_{t}$} & Czech Republic & 14 & 17 & 30 & 34 \\
\hline & & Hungary & 11 & 12 & 24 & 28 \\
\hline & & Poland & 9 & 10 & 11 & 11 \\
\hline & & Romania & 9 & 20 & 23 & 24 \\
\hline & & Bulgaria & 32 & 37 & 35 & 35 \\
\hline & & Slovakia & 67 & 55 & 37 & 31 \\
\hline & & Estonia & 8 & 10 & 10 & 10 \\
\hline & & Latvia & 19 & 33 & 27 & 28 \\
\hline
\end{tabular}

Note: the fraction of FEVD for the money supply, real exchange rate and output explained by changes in Germany's cyclically adjusted budget balance is presented for the forecast horizons of $4,8,12$ and 16 quarters.

Source: authors' own calculations.

The RER is influenced by the money supply in all countries with a floating exchange rate, with the share of money in FEVD ranging from $20 \%$ at most for 
Poland to $30 \%$ for Hungary. While the money supply has no impact upon the RER for Bulgaria, Estonia and Latvia, it is quite different in Slovakia, where excessive money is a significant factor behind RER appreciation (its share in the FEVD approaches 20\%). A direct link between the money supply and the RER implies a strong inflationary pass-through and does not contradict the result reported above: the money supply has a distinct restrictionary effect.

Finally, an increase in output is met with a loosening of monetary policy in all countries with a floating exchange rate, with the share of the business cycle in the FEVD of the money supply ranging from 15-20\% for Poland to 25\% for the Czech Republic and above 30\% for Hungary. On the other hand, the money supply does not react to output in Bulgaria and Slovakia. For Estonia, there is an inverse relationship between output and the money supply, which could be explained by concerns about the inflationary consequences of Phillips curve-type economic boom. As for Latvia, a short-run decrease in the money supply reverses in the long run. For both Baltic States, the share of output in the FEVD of the money supply is very high, in excess of $40 \%$.

\section{Conclusions}

For eight CEE countries (Bulgaria, the Czech Republic, Hungary, Poland, Romania, Slovakia, Estonia and Latvia), it is found that Germany's fiscal austerity policy has positive expansionary spillovers on impact. Regardless of the exchange rate regime, one of the transmission mechanisms implies an increase in the money supply following an improvement in the German budget balance. This means that countries with a de jure floating exchange rate regime provide a policy of targeting the exchange rate de facto. As a consequence, capital inflow resulting from Germany's fiscal austerity policy becomes a factor behind an increase in the money supply for the CEE countries, thus leading to a demand-driven expansionary effect. On the other hand, the effects of Germany's budget balance on the real exchange rate of CEE countries are rather marginal, suggesting weakness of the relative price effect in foreign trade.

In full accordance with a two-country Mundell-Fleming model, the strongest expansionary spillover from German fiscal austerity is to be expected for Slovakia and Bulgaria, followed by Latvia, as all three countries maintain a fixed exchange rate regime. However, the expansionary effect is found to be rather insignificant for Estonia, another country with a peg. Expansionary effects are somewhat weaker for countries with a floating exchange rate regime, but there is not a single case with an output being contracted on impact in response to an improvement in the budget balance in Germany, as should be the case for a 'pure' floating within 
the Mundell-Fleming theoretical framework. However, a restrictionary effect from the German fiscal shock in Hungary and the Czech Republic, with a lag of eight to 12 quarters, is likely. On the whole, our results contrast with several studies implying that a higher budget deficit in Germany is beneficial for other European countries. Among different spillover channels, demand and competitiveness effects seem to be outweighed by the effect of international capital flows.

\section{Bibliography}

Auerbach A. J., Gorodnichenko Y. (2012), Measuring the Output Responses to Fiscal Policy, "American Economic Journal: Economic Policy", vol. 4, no 2, https://doi. org/10.1257/pol.4.2.1.

Beetsma R., Giuliodori M., Klaassen F. (2006), Trade Spillovers of Fiscal Policy in the European Union: A Panel Analysis, "Economic Policy", vol. 21, no 48, https://doi. org/10.1111/j.1468-0327.2006.00168.x.

Bigio S. (2010), Learning under Fear of Floating, "Journal of Economic Dynamics \& Control", vol. 34, no 10, https://doi.org/10.1016/j.jedc.2010.04.010.

Born B., Juessen B., Müller G. J. (2013), Exchange Rate Regimes and Fiscal Multipliers, "Journal of Economic Dynamics and Control", vol. 37, no 2, https://doi.org/10.1016/ j.jedc.2012.09.014.

Calvo G., Reinhart C. (2002), Fear of Floating, "Quarterly Journal of Economics", vol. CXVII, no 2, https://doi.org/10.1162/003355302753650274.

Cardi O., Müller G. J. (2011), Habit Formation and Fiscal Transmission in Open Economies, "Journal of International Economics", vol. 85, no 2, https://doi.org/10.1016/ j.jinteco.2011.07.007.

Christiano L., Eichenbaum M., Rebelo S. (2011), When Is the Government Spending Multiplier Large?, "Journal of Political Economy", vol. 119, no 1, https://doi. org/10.1086/659312.

Corsetti G., Meier A., Müller G. J. (2012), What Determines Government Spending Multipliers, "Economic Policy", vol. 27, no 72, https://doi.org/10.1111/j.14680327.2012.00295.x.

Ilzetzki, E., Mendoza E., Végh C. (2013), How Big (Small?) Are Fiscal Multipliers?, "Journal of Monetary Economics", vol. 60, no 2, https://doi.org/10.1016/j.jmoneco.2012.10.011.

Ivanova A., Weber S. (2011), Do Fiscal Spillovers Matter?, "IMF Working Paper", no $\mathrm{WP} / 11 / 211$.

Johannsen B. (2014), When Are the Effects of Fiscal Policy Uncertainty Large?, "Finance and Economics Discussion Series", no 2014-40.

Karger H. (2014), The Bitter Pill: Austerity, Debt, and the Attack on Europe's Welfare States, "Journal of Sociology \& Social Welfare", vol. XLI, no 2.

Krugman P. (2013), Those Depressing Germans, "The New York Times", November 3.

McCallum B. (1996), International Monetary Economics, Oxford University Press, Oxford, NY.

Müller G. J. (2014), Fiscal Austerity and the Multiplier in Times of Crisis, "German Economic Review”, vol. 15, no 2, https://doi.org/10.1111/geer.12020. 
Veld J. (2013), Fiscal Consolidations and Spillovers in the Euro Area Periphery and Core, "European Commission Economic Papers", no 506.

Windberger T., Crespo Cuaresma J., Walde J. (2012), Dirty Floating and Monetary Independence in Central and Eastern Europe - The Role of Structural Breaks, "University of Innsbruck Working Papers in Economics and Statistics", no 2012-21.

Zezza G. (2012), The Impact of Fiscal Austerity in the Eurozone, "Review of Keynesian Economics", Inaugural Issue.

\section{Działania oszczędnościowe w Niemczech oraz ich makroekonomiczne skutki dla rozmaitych systemów kursu walutowego - doświadczenie krajów Europy Środkowej i Wschodniej \\ (Streszczenie)}

Zgodnie ze znanym modelem Mundella-Fleminga dla dwóch obszarów gospodarczych polityka oszczędnościowa w Niemczech powinna być jednoznacznie restrykcyjna dla innych krajów europejskich, które prowadzą politykę kursu płynnego, podczas gdy w wypadku kursu sztywnego istnieje możliwość otrzymania korzystnego efektu ekspansywnego. Na podstawie danych kwartalnych dla ośmiu krajów Europy Srodkowej i Wschodniej z lat 2002-2014 stwierdzono z wykorzystaniem modelu VAR z czterema zmiennymi, że polityka oszczędnościowa w Niemczech prowadzi do zwiększenia podaży pieniądza i dochodu, ale nie ma wpływu na realny kurs walutowy. Nie potwierdziły się wyniki kilku innych badań, które przewidują, że zwiększenie deficytu budżetowego w Niemczech jest korzystne dla innych krajów europejskich. Otrzymane rezultaty mogą oznaczać, że mechanizmy popytu i relatywnych cen są zniwelowane przez przepływy kapitału. Najsilniejszy efekt ekspansywny otrzymano dla Bułgarii, Słowacji oraz Litwy, które prowadzą politykę kursu sztywnego. Efekty ekspansywne są słabsze w przypadku krajów, które charakteryzują się większą giętkością kursu walutowego, jak Polska, Węgry i Czechy.

Słowa kluczowe: działania oszczędnościowe, Niemcy, system kursu walutowego, kraje Europy Środkowej i Wschodniej, model Mundella-Fleminga. 